\title{
Træk fra kapitulationen og retsopgøret i Sønderjylland
}

\section{af Iver Moller}

Fhv. politimester Iver Møller, Aabenraa (f. 1918) var frem til befrielsen i maj 1945 indsat i Frøslev lejren, og straks derefter fik han som politifuldmægtig vigtige opgaver i forbindelse med retsopgøret. Iver Møller fortæller her erindringer om denne mærkelige tid og fremdrager især nogle af de væsentligste anklagepunkter mod mindretallets ledelse.

Den 4. maj 1945 om aftenen gik det i Frøslevlejren som en løbeild fra den ene barak til den anden, at Tyskland havde kapituleret. Oplysningens troværdighed bekræftedes ved, at meddelelsen var opfanget fra en illegal radiomodtager $i$ lejren. Man slog skodderne fra, og enkelte steder kunne man feste med en kop erstatningste. Ved tilberedningen af teen mistede politimester Brix, Aabenraa, $2.200 \mathrm{kr}$, der var gemt i kakkelovnen. Pengene gik op i røg. Jubelen over budskabet var stor, men endnu var man fange under tysk bevogtning - og kunne ikke føle sig sikker.

Hjemtransporten fra 20. april 1945 til Frøslevlejren af danske og norske fanger fra tyske koncentrationslejre gav - selvom mange hjemførte fanger var i miserabel stand - muselmænd - forhåbning om, at krigen snart var slut.

Men usikkerheden med hensyn til afslutningen var endnu stor, idet det tyske hovedkvarter på Dagmarhus i København den 4. maj om morgenen havde givet ordre om, at 17 Frøslevfanger skulle bringes til København for at stilles for krigsret. Ved gentagne appeller og optællinger lykkedes det kun at få fat i 14, idet tre ikke kunne findes. Hen på dagen førtes de 14 til Padborg Station og anbragtes $i$ en fangevogn.

Næstkommanderende i den danske lejrledelse, øjenlæge Steffen Lund, fik tilladelse til at telefonere til Dagmarhus og fik afblæst transporten til København, idet man i Dagmarhus havde ophørt med arbejdet. De 14 førtes tilbage til lejren, og den danske lejrledelse indskærpede, at enhver form for demonstration skulle undgås, idet man ikke kunne vide, hvordan lejrens tyske personale ville reagere.

Efter modtagelsen af kapitulationsbudskabet gik den danske lejrleder, kaptajn Digmann, og politimester Brix (der skulle være politikommandør i Sydjylland) til lejrens tyske kommandant og krævede omgående løsladelse af lejrens fanger. Kommandanten kunne ikke efterkomme anmodningen (kravet), idet han ville afvente ordre fra højere sted. 
Aftalen blev, at $i$ alle tilfælde skulle løsladelse ske 5. maj kl. 12.00, idet politimester Brix sagde, at han sammen med et antal medarbejdere - politimester Bøving, Tønder og mig og orlogskaptajn Greve - ville forlade lejren kl. 10.30 .

Fængselsvæsenet, der jo som »den danske forvaltning" havde sørget for forplejningen i lejren, kørte os til Aabenraa. Det var efter udkørselen fra lejren overraskende og betagende at se, at alt var grønt. I lejren var alt pløre, så man skulle gå $\mathrm{i}$ træsko eller træskostøvler. Der var intet grønt undtagen granerne rundtom lejren.

Ved ankomsten til Aabenraa politigård gik vi op ad en hønsestige, idet hovedtrappen ikke var repareret efter Peter-gruppens sprængningsaktion i 1944 den 4. maj kl. 2 om natten.'

Politimester Brix og jeg begav os hurtigt $\mathrm{i}$ vores derangerede påklædning, der havde været til aflusning $i$ autoklaven, ned $i$ byen for at tale med den tyske general v. Blücher for at få tilsagn om våben til politi- og modstandsfolk. Vi forsøgte først at finde ham i Vestergade på Stadttheater, der var tilholdssted for tysk militær, gestapoer m.v., og hvor det antoges ikke at være risikofrit at komme ind. Generalen var der ikke, hvorfor vi tog til hans kvarter på Grand Hotel. Det var mærkeligt denne dag at møde en tysk general med røde reversopslag og brede røde striber på bukserne. Generalen var forstående og ville senere give besked, hvilket han gjorde telefonisk efter konference med generalfeltmarskal Busch, men det var negativt.

Om eftermiddagen passede jeg politimester Brix's kontor, idet Brix skulle tale med forskellige politimestre i Sydjylland. Jeg kunne ikke forlade kontoret, men kunne hen på aftenen se de første engelske soldater komme forbi til Folkehjem, hvor der var samlet en stor folkemængde.

Samme aften begyndte modstandsbevægelsen at foretage anholdelser af personer, der havde samarbejdet med besættelsesmagten. Modstandsbevægelsen havde anholdelsesret til 13. maj, hvorefter anholdelsesretten lå hos politiet. Grundlaget for anholdelserne var dels udarbejdede lister og kartoteker, dels personligt kendskab. Der var et meget stærkt folkekrav om et hurtigt og strengt retsopgør med dem, der havde samarbejdet med besættelsesmagten.

I straffeloven fra 1930 findes en regel i § 101, stk. 2, der siger, at »den, der under krig eller truende udsigt til krig hjælper fjenden, straffes med fængsel fra 1 år til 12 år«. Der var almindelig enighed om, at denne lovbestemmelse ikke kunne danne grundlag for retsopgoret, idet der kunne være tvivl om, hvorvidt der i alle fem besættelsesår forelå krig, eller om en sådan tilstand først var indtrådt fra 29. august 1943.

Under besættelsen havde det jo selvsagt varet helt umuligt at vedtage straffebestemmelser for samarbejde og hjælp til besættelsesmagten. I slutningen 
af besættelsen udarbejdedes der i Justitsministeriet og i Frihedsrådet detaillerede lovforslag med strafferegler. Der var tvivl om, hvordan det strafbare skulle afgrænses. Således var det i Frihedsrådet under overvejelse, om medlemskab i et nationalsocialistisk parti - som i Norge - skulle være strafbart.

Jeg deltog i foråret 1945 i København i et møde, hvor spørgsmålet drøftedes. Jeg gik imod, idet det ville være helt uoverkommeligt i Sønderjylland, hvor der fandtes mange nazister, både tysksindede og dansksindede. Spørgsmålet droppedes.

I løbet af maj måned behandledes forslag til straffelovstillæg, og det gav anledning til langvarige drøftelser, specielt angående straffelovens tilbagevirkende kraft, strafminimum på 4 år og indførelse af dødsstraf samt retsplejebestemmelsen om, at sigtede skal fængsles og forblive fængslet, indtil straffen er udstået. Rigsdagen balancerede sig frem til en løsning, der kunne accepteres af Frihedsrådet og politikerne, idet man var klar over folkekravet om strenghed og hurtighed. Medvirkende til udformning af reglerne var også, at man ville undgå »de lange knives nat«.

Som formanden for Frihedsrådet, fhv. minister Frode Jacobsen, har meddelt mig, skete der ved kapitulationen i Frankrig et meget stort antal likvidationer. Der findes to redegørelser, $i$ den ene angives tallet for likvidationerne til 45.000, og i den anden til 100.000. Ingen af likvidationerne er senere blevet undersøgt af myndighederne. Noget lignende blev heldigvis undgået her i landet. Kun ganske få - ca. 10 - likvidationer fandt her sted efter kapitulationen, og de blev omhyggeligt undersøgt, $\mathrm{i}$ de fleste tilfælde med store psykiske problemer for dem, der havde deltaget i aktionerne.

Antallet af anholdte i løbet af maj-juni var stort - omkring 700 i Aabenraa politikreds, eller omtrent hver 10. voksne mand. Afgrænsning af det strafbares område var vanskelig, specielt før lovens vedtagelse. Væsentligt var, at "nde mest sikre grupper«, såsom mindretalsledelsen og de, der havde forrettet tysk krigstjeneste samt stikkere og gestapomedhjælpere blev anholdt. Men tvivlsomme tilfælde måtte vente.

De anholdte blev bragt ind til det tyske gymnasium, hvor de blev registreret og derefter overført til Fårhuslejren, hvor der snarest muligt afholdtes grundlovsforhør, ca. 30 pr. dag, idet dommer, forsvarer og anklager tog til Fårhuslejren. Løsladelse skete på grund af bestemmelserne i retsplejelovstillægget kun meget sjældent.

Blandt de dømte var de fleste folk, der havde forrettet tysk krigstjeneste. Hyppigst var det tjeneste i Waffen-SS, men der var også tale om tjeneste $i$ andre afdelinger. Herudover var der Zeitfreiwillige, ${ }^{2}$ marinevægtere og andre vagtmænd samt bevæbnede brandmænd.

Retsbehandlingen skete med få undtagelser ved domsmandsret, idet man 
ikke ønskede sagerne behandlet som tilståelsessager. Fire til fem domsmandssager kunne behandles af retten pr. dag. "Seriesagerne« kom først for retten. De, der blev dømt først, fik de strengeste straffe.

I juni 1946 nedsattes strafminimum fra fire år til to år med mulighed for yderligere nedsættelse. SS-sagerne blev afgjort med to - et års fængsel, marinevægterne ofte med fire år, brandmænd med et år og Zeitfreiwillige med to - halvandet år. Behandligen af Zeitfreiwillig-sagerne ved retten stilledes $\mathrm{i}$ bero i nogen tid, idet mindretalsledelsen påstod, at der fra Kanstein (chef for Innere Verwaltung i det tyske gesandtskab i København) var sendt en skrivelse, der meddelte, at der af den danske regering var givet tilladelse til oprettelse af korpset. Man hævdede fra mindretalsledelsen, at skrivelsen umiddelbart før kapitulationen desværre var blevet brændt. Da Kanstein dukkede op fra krigsfangenskab og overførtes til København, afhørte jeg ham straks, og han udtalte klart, at han aldrig havde sendt en skrivelse som omtalt, idet han var helt klar over, at korpset var ulovligt. For at fjerne enhver tvivl bad jeg ham om på tysk at diktere, hvad han havde forklaret. Herefter blev Zeitfreiwilligsagerne fremmet.

Sagerne mod mindretalsledelsen og de ansvarlige for "Nordschleswigsche Zeitung"

At sagerne mod mindretalsledelsen, der omfattede medlemmerne af »Kleiner politischer Rat ${ }^{3}$ og redaktører og bestyrelsesmedlemmer fra den tyske avis, behandledes samlet, skyldtes politimester Brix's beslutning og klarsyn, idet der var nøje sammenhæng mellem disse sager, som krævede undersøgelser og afhoringer af generel betydning til belysning af hver enkelts strafferetlige ansvar.

Til behandling af sagerne, der ikke kunne klares af Aabenraa politi alene, etablerede politimester Brix en særlig undersøgelsesafdeling, idet hver politikreds i området fra Varde-Horsens til landegrænsen skulle sende to kriminalpolitimænd til Aabenraa. Herudover traf politimester Brix aftale med Troels Fink, der i 30'erne havde været sekretær hos politiadjudanten i Aabenraa og senere som lektor og docent ved Aarhus Universitet nøje havde fulgt udviklingen i Sønderjylland, herunder bevægelser i det tyske mindretal og forbindelser til rigstyske myndigheder og organisationer, om at bistå politiet ved vurdering og forståelse af dokumenter og afgivne forklaringer. Denne bistand var meget nyttig og af stor betydning.

I Politiadjudanturens arkiver fandtes ganske vist materiale, der kunne bruges ved behandling af straffesagerne mod mindretalsledelsen, men det viste sig 


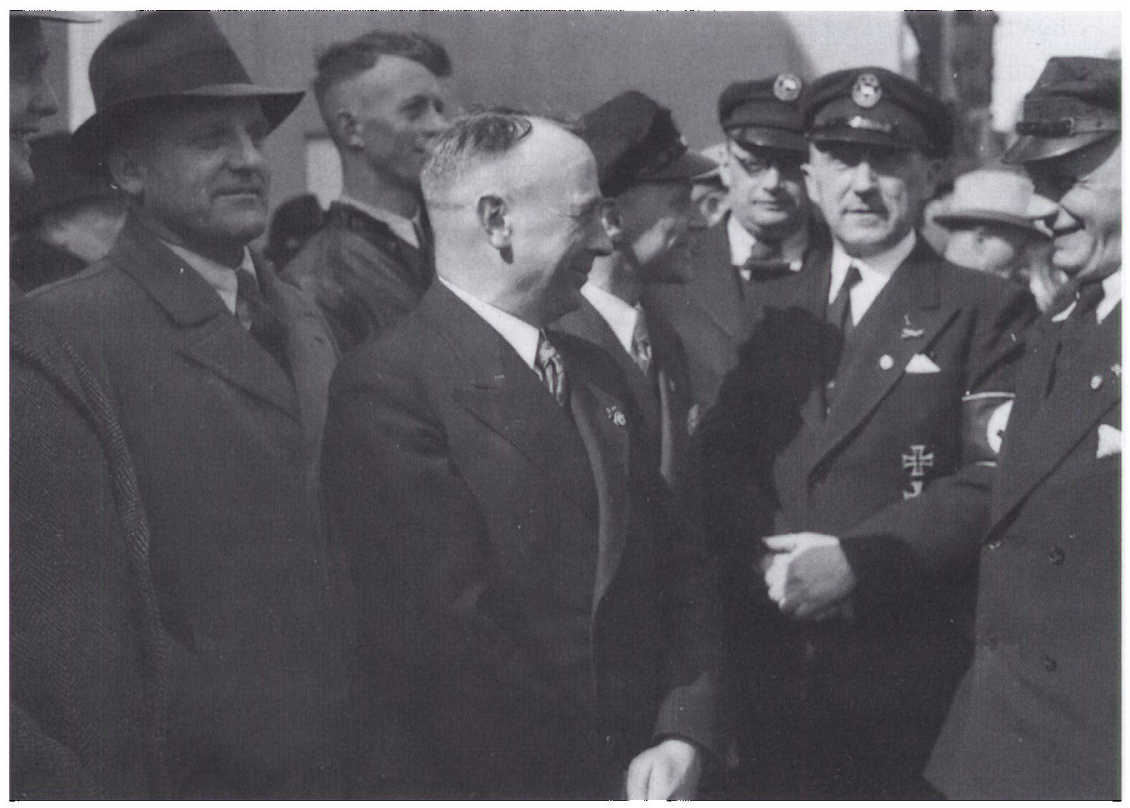

Nogle af udet lille politiske rådus medlemmer. Fra venstre Jens Moller, Jep Schmidt, Harboe Kardel, Lauritz Clausen (nr. 2 fra h.) og Rudolph Stehr (yderst t.h.). Historiske Samlinger, Aabenraa.

snart, at det var meget spredt og kun i ringe grad var til nytte ved efterforskningen. Ved beslaglæggelser hos anholdte og i private arkiver lykkedes det at finde frem til en del skriftligt materiale, der kunne bruges som bevismateriale. I mindretallets højborg "Dibbernhaus« i Aabenraa havde man derimod i dagene op til kapitulationen tilintetgjort og brændt alt, hvad der kunne tænkes at være kompromitterende.

For at have noget, der kunne bruges som vejledning og hjælp ved afhøringerne anmodede politimester Brix mig om at skrive nogle redegørelser til »Besættelsestidens Fakta«, der redigeredes af højesteretssagfører Alkil. Det blev til tre redegørelser vedrørende det tysk naziparti's (NSDAPN) opbygning, om Zeitfreiwilligkorpset og om Selbstschutz. ${ }^{4}$

Efterforskningen krævede mange afhøringer her i landet, bl.a. af besættelsesmagtens hovedpersoner: dr. Werner Best, der var Reichsbevollmächtigter, general Hermann v. Hanneken, general Lindemann, politigeneral Pancke, gestapochef Bovensiepen, chefen for Innere Verwaltung Kanstein m.fl., der alle var arresterede i København. Herudover skulle der afhøres adskillige, der var i Tyskland. Men efter de dengang herskende forhold var det meget ofte vanskeligt at finde ud af, hvor de opholdt sig. Nogle var arresterede, andre var på fri fod. 
Slesvig-Holsten's Gauleiter Hinrich Lohse sad i en tidligere koncentrationslejr Esterwegen i Ostfriesland, overborgmester Kracht fra Flensborg sad i Neuengamme, statssekretær Ernst Freiherr v. Weizsäcker sad i Nürnberg og SS-general Lorenz (leder af Volksdeutsche Mittelstelle) ${ }^{5}$ sad i Landsbergfængslet, dér hvor Hitler havde siddet i 1923.

Jeg deltog jævnligt i afhøringerne i Tyskland og af besættelsesmagtens hovedpersoner i Danmark. Det var ikke altid, at man ved afhøringerne fik den fulde sandhed. Der blev gjort, hvad der var muligt for at få alle relevante forhold belyst så godt som muligt, så man kunne få grundlag for tiltale og domfældelse.

På et ret sent tidspunkt fik danske myndigheder adgang til et stort dokumentcenter i Berlin, der var i amerikanernes varetægt. En delegation bestående af landsarkivar Hvidtfeldt og arkivar Harald Jørgensen, Rigsarkivet, fuldmægtig Kjøgx fra Justitsministeriet og kriminaloverbetjent Sjørup tog til Berlin, gennemgik dokumenter og tog afskrift af de væsentlige papirer, der forsynedes med underskrifter af alle fire til bekræftelse af afskriftens rigtighed - kopimaskiner stod jo dengang ikke til rådighed. Afskrifterne blev sendt til politimesteren i Aabenraa, hvorfra de forelagdes Justitsministeriet til afgørelse af, om de måtte anvendes. Efter returnering fra Justitsministeriet sendtes de relevante dokumenter til translatør-oversættelse og kunne derefter bruges ved afhøringer i de enkelte sager. Det var en kompliceret fremgangsmåde, men der fremkom meget godt bevismateriale, bl.a. fra Auswärtiges Amt's og andre centralmyndigheders arkiver.

I denne forbindelse kan nævnes, at jeg fra pastor Rishøjgaard, Rise, der havde været i USA og i forsvarsministeriet Pentagon, fik overdraget et større antal dokumenter, der havde væsentlig betydning ved behandlingen af ca. 10 spionsager ved retten i Tønder. Dokumenterne indeholdt meldinger af militær betydning afgivet af spionerne før den tyske indmarch i Danmark den 9. april - og var forsynet med spionens spion-nr., således at meldingerne kunne henføres til bestemte personer, idet officerer fra den militære tyske efterretningstjeneste Abwehr havde opgivet, hvem der havde hvilket nr. og bogstav. f.eks. R. 16.

\section{De afhørte "nøglepersoner" - oplevelser og vurderinger}

Afhøringerne af de mange tyske nøglepersoner gav også mulighed for at vurdere de pågældendes personlige egenskaber. Det var selvsagt med noget blandede følelser man sad overfor og samtalede med de personer, der kort forinden under besættelsen havde kunnet skalte og valte efter forgodtbefin- 
dende med danske borgeres liv og ejendom. Men nu var de jo arresterede og kunne ikke gøre skade. For adskilliges vedkommende måtte forklaringerne tages med et vist forbehold, idet nogle havde svært ved at frigøre sig for deres tidligere position og for en følelse af at ved at fortælle hele sandheden begik de en slags forræderi. Men jeg oplevede naturligvis undtagelser.

Redaktør Friedrich Wilhelm Ernst Schroder, der var søn af en gymnasielærer og født i Haderslev (1.10.1889) og dansk statsborger, havde igennem et langt liv haft sit virke i Flensborg, og blev bl.a. i 1931 formand for bestyrelsen for Nordschleswigsche Zeitung indtil kapitulationen. Han var på mange måder en magtfuld person som mellemmand mellem rigstyske myndigheder og organisationer og mindretallet. Hans meninger m.h.t. mindretalspolitikken blev tillagt så megen vægt, at han fik betegnelsen "Der politische Weichensteller«. Schröder var $\mathrm{i}$ besiddelse af humoristisk sans og stor viden angående personer, der havde virket $i$ tysk grænselandsarbejde, og om personer der efter kapitulationen på dette område ville frem i første række. Han fortalte åbent og ærligt, men nåede desværre ikke at skrive sine erindringer.

Staatssekretær i Auswärtiges Amt, friherre von Weizsäcker, som jeg afhørte i krigsforbryderfængslet i Nürnberg angående mindretallets grænseflytningsbestræbelser, gav indtryk af at være en mand med en fin karakter, og han optrådte åbent og ærligt.

Lederen af Volksdeutsche Mittelstelle, SS Obergruppenführer Werner Lorenz, blev afhørt i Landsberg-fængslet ved Garmisch-Partenkirchen. Han var idømt 20 års fængsel og kunne ikke forklare noget væsentligt, men kun understrege det officielle tyske standpunkt om, at man ikke ville flytte grænsen. Man fortæller om ham, at han havde fảet sin høje rang og stilling, fordi han i forste verdenskrig var flyverkollega med Göring og havde et lavt partinummer. Han kunne uden anmeldelse gå ud og ind hos Hitler i Berlin.

Oberpræsident og Gauleiter Hinrich Lohse, der havde hersket over SlesvigHolsten, var idømt 10 års fængsel og blev afhørt i den tidligere koncentrationslejr Esterwegen i Ostfriesland, hvor han ikke befandt sig vel. Han kunne ikke - bortset fra to samtaler med Hitler (i 1939 og 1943) angående grænseflytningsproblemet - forklare noget væsentligt nyt, hvorfor hans ønske om at blive overført til Danmark ikke kunne imødekommes. Han kunne ikke rigtig affinde sig med sit fald fra den magtfulde stilling som Gauleiter.

Den tidligere gesandt i København, Cecil v. Renthe-Fink, blev et par år efter kapitulationen overført fra Tyskland til Aabenraa arrest. Herfra skulle han næste dag sendes til København. Jeg beordrede ham visiteret for at undgå selvmordsforsøg under anholdelsen. Han var meget utilfreds hermed, men efter samtale undlod han at klage til Udenrigsministeriet.

Han spurgte meget interesseret, hvordan det var gåt forskellige politikere 
og fremtrædende erhvervsfolk. Han kunne ikke forstå, at Erik Scavenius på grund af påståt tyskvenlighed »var lagt på is«, for som han sagde: Scavenius var overhovedet ikke venlig. Overfor andre - herunder navngivne erhvervsfolk, der ikke var i søgelyset, kunne der derimod være grund til at rette bebrejdelser for tyskvenlighed.

Besættelsestidens tyske magthavere i Danmark vil jeg kun nævne ganske kort. De blev ofte afhørt og flere gange overført til Aabenraa, idet deres forklaringer skulle fastlægges i retten, før de muligvis skulle bringes til krigsforbryderdomstolen i Nürnberg som vidner.

SS-Brigadeführer Paul Kanstein, der før sin tiltræden som "Chef für Innere Verwaltung « i Danmark, havde været vicepolitipræsident i Berlin, afgav en meget væsentlig forklaring angående Zeitfreiwilligkorpset. Han fortalte mig, at han før dr. Best kom til Danmark havde fået tilbudt stillingen som Reichsbevollmächtigter - den stilling, som Best fik. Men Kanstein havde sagt nej og lod sig indkalde som soldat. Han gjorde bl.a. tjeneste i Italien, hvor han blev taget til fange. Han gjorde indtryk af at være en fuldtud ærlig og hæderlig mand. Om flere tilfælde fremhævede han, at han spillede med åbne kort overfor danske forhandlingspartnere.

Obergruppenführer og General der Polizei Günther Friedrich Wilhelm Pancke, der på grund af erfaringer fra Frankrig ved dettes kapitulation besluttede opløsning, arrestation og deportation af dansk politi den 19. september 1944, vurderedes ikke højt af general v. Hanneken. Han mente, at man i stedet for Pancke kunne have sat den kleinen Schuster vom Keller in der Seitenstrasse« på posten som politigeneral. General Hermann v. Hanneken var øverstkommanderende for de tyske tropper i Danmark indtil foråret 1945. Han havde tidligere været leder af Görings 5-års plan for rustning. Han var uden tvivl en hård negl. Han bestemte bl.a. indførelse af undtagelsestilstanden den 29. august 1943 med heraf følgende rigoristiske forskrifter og straffebestemmelser. Hans forhold til dr. Best var anspændt, idet de to jæunligt rivaliserede om førstepladsen. Som anholdt finder jeg, at Hanneken optrådte som et mandfolk, og hans forklaringer forekom ærlige. Det faldt i min lod efter løsladelsen at føre v.Hanneken ud af kongeriget. Da han ikke havde penge til vidererejse fra Flensborg, tilbød han mig at købe sit guldarmbåndsur, som han med inskription havde fået af Göring som tak for arbejdet med 5-års-planen. Jeg afslog, idet jeg sagde, at sådan noget gør en dansk embedsmand ikke. Vi kørte til posthuset i Flensborg, hvor han efter en telefonsamtale med en datter fik overført et pengebeløb, hvorefter jeg afleverede ham på banegården.

Reichsbevollmächtigter $d r$. Werner Best blev gentagne gange afhørt til politirapport $\mathrm{g}$ i retten. Han var gennemgående forsigtig og forbeholden med sine 
forklaringer. Man kunne mærke, at specielt i tilfælde, hvor noget ubehageligt kunne ramme ham, lagde han megen vægt på at sætte sig selv $i$ en gunstig position.

Under en afhøring i København kort efter udgivelsen af Gisevius' bog »Bis zum bitteren Ende«, som indeholdt en lidet smigrende karakteristik af Best, spurgte jeg Best, om han kendte Gisevius. Han svarede: "Ja, er ist ein guter Freund von mir« - han havde tydeligvis ikke last bogen. Best var en meget sammensat natur. En del under besættelsen kunne være gået værre. Hvad ville Best have gjort efter krigen med en forventet tysk sejr? Best var ikke nem at blive klog på, og det var ikke altid, at man kunne stole på hans forklaringer.

\section{Anklage og dom}

For alle medlemmerne af »Kleiner politischer Rat« blev der rejst tiltale for fire hovedforhold:

1) Hvervning til tysk krigstjeneste.

2) Oprettelse af Zeitfreiwillig-korpset.

3) Oprettelse af Selbstschutz-korpset og

4) Skansegravning (tværs over Sønderjylland)

Herudover rejstes der tiltale mod hver enkelt for »individuelle forhold«. For dyrlæge Jens Møllers og Oberleutnant Peter Larsens vedkommende skal her nævnes tiltale for overtrædelse af straffelovens $\$ 98$ - højforræderi - bestræbelser for indlemmelse af Sønderjylland i Tyskland.

Sagen blev behandlet ved retten i Aabenraa. Dommer Levinsen havde veget sit sæde, idet han $i$ et dokument af mindretallet blev beskyldt for at være "Judenrichter«. Dommer Sigurd Andresen, Haderslev, udnæuntes til sættedommer. Politimester Brix var anklager, og jeg var hans sekretær.

Sagens behandling ved retten i Aabenraa strakte sig over 88 retsdage, og dommene afsagdes 10. september 1948. Jens Møller og Peter Larsen idømtes hver 15 års fængsel, Rudolf Stehr 10 års fængsel, Otto Kortsch 12 års fængsel, Lauritz Clausen 12 års fængsel og Asmus Wilhelm Jürgensen ("Asmus von der Heide«) 10 års fængsel.

En del af de domfældte appellerede dommen til Landsretten, der efter 66 retsmøder afsagde dom i juni 1949, hvor der skete nedsættelser. Således fik Jens Møller og Peter Larsen 12 års fængsel, Otto Kortsch og Lauritz Clausen 9 års fængsel og Asmus Jürgensen 7 års fængsel.

Lad os nu se på de fire hovedforhold, som indgik i sagerne: 
Hvervning til tysk krigstjeneste

I tiden efter krigsudbruddet i september 1939 og frem til 9. april $1940 \mathrm{blev}$ der foretaget hvervning til Waffen-SS. Mindretalsledelsen var meget tilbageholdende med at afgive forklaring herom. Men i dyrlæge Jens Møllers private arkiv fandtes en indberetning af 15. april 1942 fra ungdomsfører Jef Blume, og den var ret oplysende:

I vintermånederne 1939, muligvis i marts 1940 kaldtes Peter Larsen, Lauritz Clausen og Blume til Flensborg til konference med SS-brigadefører Berger. Til stede ved konferencen var bl.a. overborgmester Kracht og SS-Untersturmführer Meissner. Berger forklarede, at efter Førerens ordre skulle der hverves til Waffen-SS i de folketyske områder. De hvervede skulle efter afsluttet tjeneste i Waffen-SS gøre tjeneste i Nordslesvig som værnebønder, politiske ledere etc. Fra nordslesvigsk side ytrede man betænkeligheder, idet planen stred mod folkegruppeledelsens ønske om at holde ungdommen $i$ hjemstavnen. Efter at Berger havde lovet, at der altid var mulighed for at vende tilbage, og fremfor alt, fordi befalingen efter Bergers udsagn udgik direkte fra Føreren, bøjede folkegruppens repræsentanter sig for det fremsatte krav og iværksatte

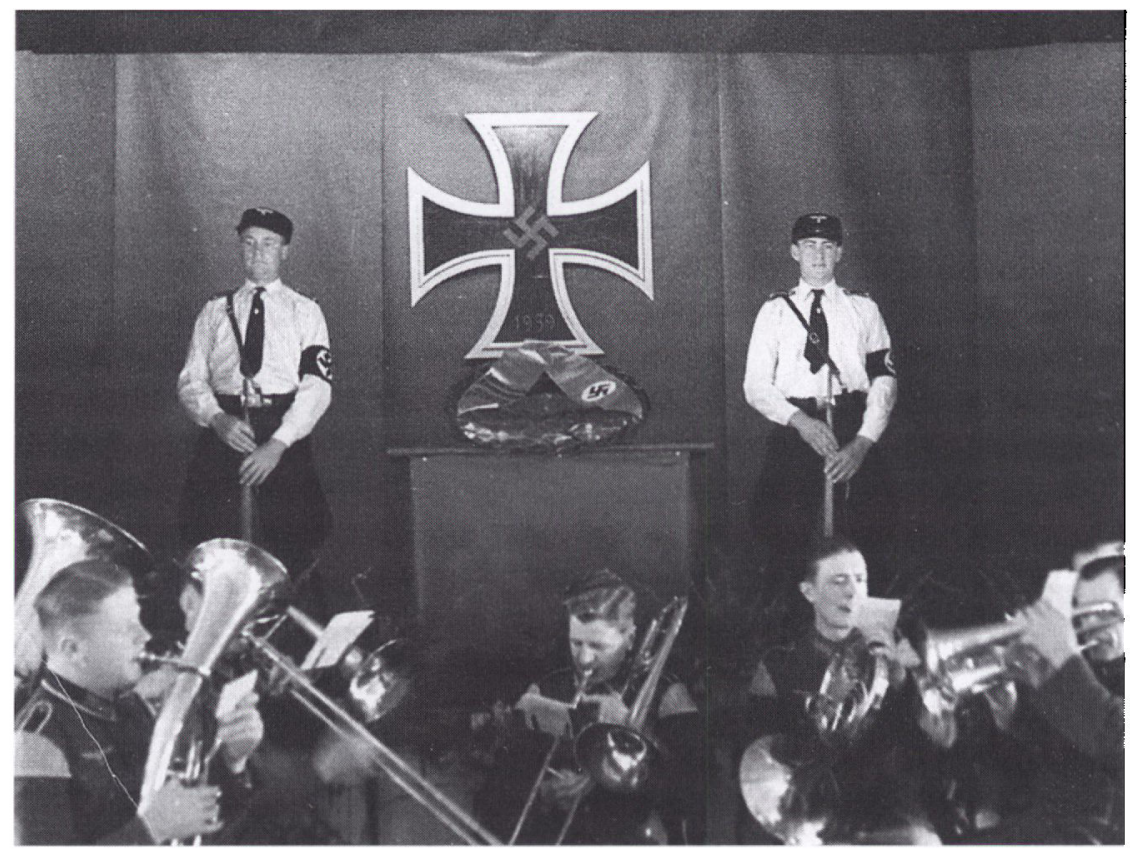

Mindretallet mistede mange medlemmer ved fronten. Hjemme blev der holdt mindehøjtideligheder på tysk "Helden-Ehrung". Foto 1943 i Historiske Samlinger, Aabenraa. 
"underhånden « hvervning i S.K. ${ }^{6}$ og D.J.N., ${ }^{7}$ hvilket resulterede $\mathrm{i}$, at ca. 100 meldte sig. 50-60 af disse blev mønstret som duelige og indkaldtes. Uddannelsen begyndte i Hamborg-Langenhorn.

Efter ca. to måneders uddannelse meddelte man nordslesvigerne, at de $\mathrm{i}$ henhold til ny befaling skulle erhverve sig tysk indfødsret. Det bragte de nordslesvigske SS-folk i en alvorlig konflikt, idet de ikke ønskede at opgive deres danske indfødsret. Det endte med, at 30-35, der ville fastholde deres danske indfødsret, blev afskediget fra SS og sendt hjem. 17 forblev i tjenesten og fik tysk indfødsret 13. august 1940. Denne hvervning, der foretoges før 9. april 1940, omfattedes ikke af tiltalen, men har en vis historisk interesse.

Umiddelbart efter besættelsen begav politipræsident Müller, Flensborg, sig incognito $i$ en Luftwaffe-bil til Nordslesvig for at intensivere hvervningen, først ved drøftelser med dyrlæge Møller og Peter Larsen og kort efter ved møde på Stadttheater i Aabenraa med 30-50 personer, der var ledende indenfor mindretallet. Han gjorde rede for den planlagte hvervning, og gjorde rede for, at han alene satte sin lid til folkegruppens Organisationsamt ved gennemførelsen af hvervningen, bl.a. ved at de pågældende blev tilsagt til session gennem folkegruppen. Sessionerne foregik som mønstringer, hvor de fremmødte blev mønstrede og lægeundersøgt.

Chefen for SS-Ergänzungsamt nævner i en hemmeligstemplet skrivelse dateret 16. juni 1940, at politipræsident Müller ved mødet med folkegruppen skulle sige folkegruppens fører sin mening om den sabotage mod rekrutteringen, der hidtil havde fundet sted.

I den første tid efter besættelsen foregik mønstringer på grundlag af lister fra Organisationsamt (Peter Larsen) under betegnelsen "Gesundheitsüberprüfungen«, og de gik jævnt over i egentlige sessioner. Efter krigen mod Rusland og efter oprettelsen af Frikorps Danmark blev disse forstærket.

Det vakte en del misstemning hos mindretallet, at man brugte "Wehrsportkursus« i Klagenfurt som lokkemad, hvorefter man, når de unge var kommet til Tyskland, pressede eller søgte at presse dem ind i SS. Man kunne heller ikke lide, at transporterne af de unge over grænsen foregik i lastvogne tildækket med presenninger.

I hvervningerne og sessionerne deltog ledende personer fra mindretallet, bl.a. Lauritz Clausen som S.K.-leder. Af SS blev han »underhånden « informeret om tid og sted, hvorefter han udsendte meddelelser om sessionerne. Rundt om $\mathrm{i}$ Sønderjylland, ja så langt borte som f.eks. Aalborg deltog Clausen i sessionerne. Han opfordrede på møder, som partiet indkaldte til, meget kraftigt til at melde sig og udtalte bl.a., at de frivillige var et forbillede for den tyske ungdom i Nordslesvig. Ved nogle møder opfordrede han dem, der ville melde sig til SS, til at rejse sig. Der forligger også oplysninger om, at han opstillede de 
fremmødte på en række og opfordrede dem, der meldte sig, til at træde tre skridt frem. Da en del var blevet stående i rækken, tilføjede han: "Nur die Schweinhunde bleiben stehen «.

Der blev $\mathrm{i}$ det hele taget lagt pres på for at få så mange tilmeldinger som muligt. I en skrivelse af 29. januar 1942 oplyste Peter Larsen, at der var hvervet ialt 790 til Værnemagten og Waffen SS, og at der på dette tidspunkt stod 550 i Waffen SS. Fra februar 1942 gik partiet (NSDAPN) fuldt og helt og officielt ind for hvervningen og organiseringen af denne. Dyrlæge Møller havde været kaldt til Berlin, hvor man havde forlangt flere frivillige.

Hvervekampagnen foregik med stor kraft. Partiføreren udstedte 10. februar 1942 et opråb til folkefællerne omfattende årgangene 1902-23. Der holdtes hvervemøder, hvor partiets bedste talere var $\mathrm{i}$ virksomhed, og der agiteredes iøvrigt kraftigt for hvervningen. I en indberetning af 21. april $1942 \mathrm{fra}$ gesandt Renthe-Fink meddeles, at hvervekampagnen har medført tilmeldelse af 1402 folketyskere. Berlin var ikke tilfreds og forlangte en intensivering. Der blev holdt små lokale SK-møder, og der nævnes også eksklusion af partiet af dem, der ikke havde meldt sig.

Spørgsmål om uundværlighed (»Unabkömmlichkeit«) for dem, der havde

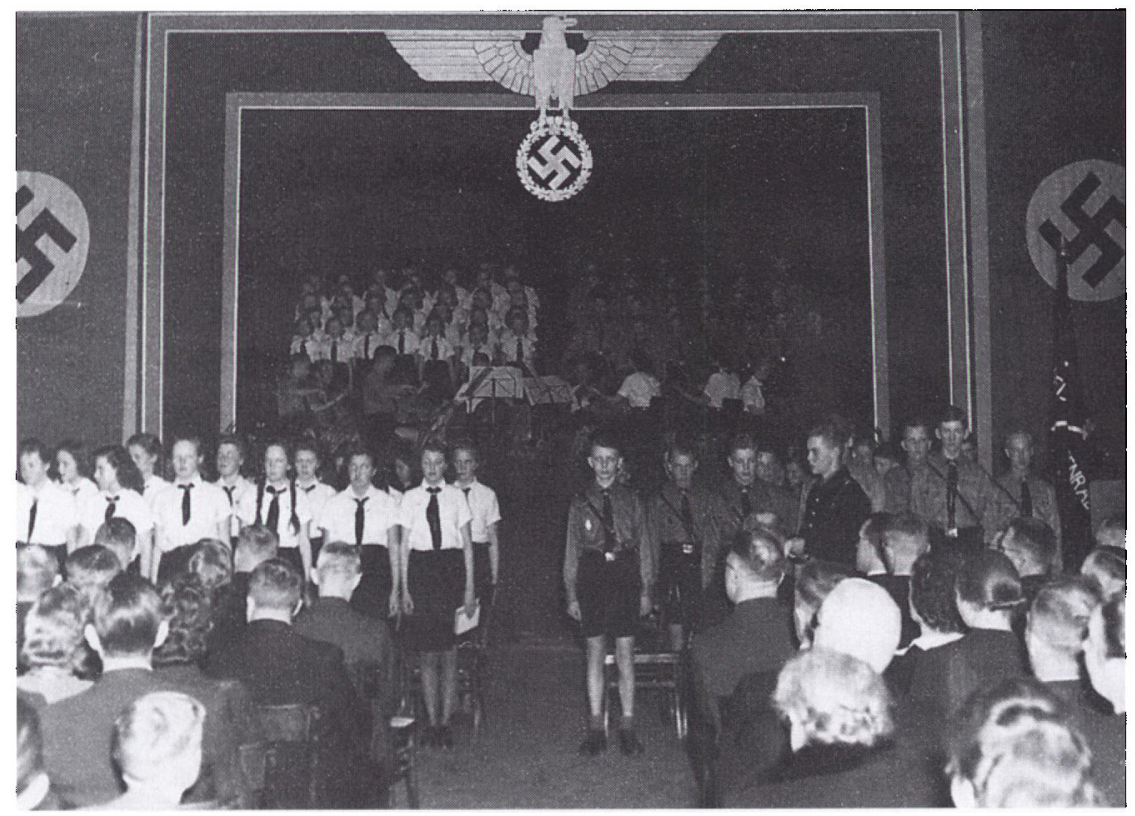

"Verpflichtung der deutschen Jugend in Apenrade 2.4.1944" lyder påskriften på dette billede. Historiske Samlinger, Aabenraa. 
meldt sig, kom frem for sønner af gårdejere eller indehavere af forretninger eller personer med politiske poster. I 1942 blev den slags spørgsmål afgjort straks efter sessionsbehandlingen af dyrlæge Møller. Fra 1943, da man fra rigstysk side fandt, at for mange blev erklæret "unabkömmlich «, forelagdes sagerne i det lille politiske råd, men det var Berlin ikke helt tilfreds med.

I indberetningen pr. 1. januar 1945 meddeler dr. Best, at der findes 1391 frivillige ved Waffen SS, 507 ved Værnemagten, 36 ved Flakskytset, ${ }^{8} 89$ ved Grænse- og Toldbeskyttelsen, ialt ca. 2.000, hvor man hos mindretallet pr. 30 . november 1944 har haft ialt 385 faldne og sårede.

I krigens allersidste periode etablerede ungdomsforeren Thorius en ungdomshvervning blandt de helt unge. Det lille politiske råd ville ikke have med denne hvervning at gøre. En række ganske unge meldte sig i april 1945 og indkaldtes til tysk krigstjeneste, men nảede ikke at gøre aktiv krigstjeneste.

Alle medlemmer af det lille politiske råd blev dømt for overtrædelse af straffelovstillæggets $\S 10$, stk. 1 , for de i rådet trufne beslutninger om hvervning.

\section{Zeitfreiwilligendienst}

Den egentlige Zeitfreiwilligendienst bestående af danske statsborgere inden for det tyske mindretal oprettedes i foråret 1943. I folkemunde på dansk side kaldte man det "Heimwehr«.

Det er ikke helt klart, hvem der tog initiativet til korpsets oprettelse, om det var general v. Hanneken eller mindretallet. Forbilledet var den i efteråret 1942 oprettede militære organisation for her $\mathrm{i}$ landet boende tyske statsborgere, der i begyndelsen kaldtes Zeitfreiwillige og senere Noteinsatzpflichtige.

Noget tyder på, at mindretalsledelsen var meget interesseret $\mathrm{i}$ oprettelsen, idet man således måske kunne undgå presset fra SS-Ersatzkommando Dänemark om at sende folk til fronttjeneste i Waffen SS. Den tyske konsul i Aabenraa havde indberettet til den befuldmægtigede, at oprettelsen af et sådant korps ville bevirke et chock $\mathrm{i}$ den danske befolkning. Ved oprettelse af det hjemlige korps kunne man også fjerne en vis misfornøjelse hos de "små« medlemmer i anledning af den måde, princippet om »Unabkömmlichkeit« var praktiseret på.

Ifølge forklaring fra dyrlæge Møller havde general v. Hanneken udtalt, at han forudså, at der i tilfælde af allieret invasion kunne blive tale om generalstrejke. I den situation ville det være ønskeligt at have en organisation, der kunne besætte og betjene livsvigtige virksomheder såsom gas-, elektricitets- og vandværker i Nordslesvig, evt. i hele Jylland. Organisationen kunne også anvendes til transportformål. Dyrlæge Møller henvendte sig nu til SS-Brigadeführer Kanstein, der var chef for Innere Verwaltung i det tyske gesandtskab i Kbh. Han skulle sørge for tilladelse hos danske myndigheder. Møller forklare- 
"Der Standort션Iteste

A $p$ e $r$ a d e

- - - - - - - - -

lierkblatt fir den Jeitfreiwllligek.

- $-\ldots \ldots$

1). Nach Brhalt der Einberufung steht der 3eitfreiwillige nur unter den deutschen Niliturgesetzen.

2). Er untcrsteht den Standortaltesten seines Wohnbezirlres und ist von diesen einer niliturischen Einsatzdienststelle zugeteilt.

3). Als Iegitimation besitzt der Jeitfreiwillife einen Ausveis, der von Standortaltesten ausgestellt ist. Die Arwbinde "Deutsche Wehracht" darf nicht zur Uniforz getragen werden.

4). Nach Einberufung ist der Jeitfreivillige, den deutschen Hohruachtsangchoricen sowonl wohrsola- wie versorgungsmassig gleichgestellt.

5). Belleidung und Ausristung hat Aivr zeitfreirillisc in seiner : iohnung sichor zu verschron und instand zu halten.

6). Wafien und Iunition enprungt or in Jalle oines Jinsatzes bei $a \in r$ fir inn zustenaigon ailitariscicon Einsatsilenststezle.

7). Beir Ausschcidon aus dea peitsorwilligenaienat in Standortgebiet Apenzicio, sei es curch Franliheit, Sinberuiung zur iehrmacht, thersiedlung in einen andcren Polizeilmot.s oder aus anceren Grinacn hat der Jeitireivillige Tuizorm, Ausristung, Arrbinde und Auswois boi der Wehrachtkomanciantur Apenrade wieds abzuijuern. Ir hat sich i: neuon Wohnort unverzüslich bei der iHchsten Vehrrachtdienstateile zu nolcien.

8). Jeder 7eitreiwillige ist in den Jinsetz einer "Alarngripe" einer militurischon Jienststelle in Stendortgebiet zugetoilt.

9). Nach Erinalt âes Gestellungsbeiehles hat en sich voi Cer Einsatziisnatstelle unverzijifich zu melden.

10). Der Sestiellungsbetehl wind don Jeitreivizligen nindlich ober telcionisch durch cien zustundien Grup- 
penithrer aui Beilil scinor :-iZiturischen Binsatzdienst iber:ittelt.

11). Wenn nicht ausdruicirlich anders befohlen, hat der zeitfreivilifee zur Dienst ir tniforn zu erscheinen.

12). Der 3eitfreivilifge hat jocien Hohnungswechel unver: züflich der Tehriachtko:mandantur ipenrade und seiner Jinsatzciienststelie zu melien.

13). Bei Intfernung aus dez Stanciort iber 24 Stunien (írlaub, Geschaftsreise ust.) ist die Jehrzachtsirozrarcantur Apenrade von der dbreise in Ienntinis zu sotzer.

14). Ein Verlassen des Staniortes whinrend des Llarmustandos ohne Gazehri zux der. Jehr:iachtlow:andantur. ist verboten.

15). Der zeitfreiriliige hat in - und eusser Dienst ein lrow:-lites und der deutschen Tehrnacht wirdices 3enehnen zu zeigen. In iat sich jeder Provolration der dunischen 3iviluevolkervig ožer den dünischen Beh甘rde gegenuiber zt: entha.ticn.

16). tber jeảes besonderc Vorkommis wie nZusaimenstoss nit dunischen 3jvilisten ocen denischer Polizci, Sabotageverdacht oder Sabotagehandlung, Spionage, Fallschirnabsprung, Flugzeugabschuss, Notlandung usw." hat der zeitfreiwillige unverallelich, ohne aivilisten oder danische Behorden davon in Kenntnis zu setzen, seiner niliterrischen Dienststelle lieldung zu erstatten.

Die weitere Verfolguns der Angelegenlcit ubernimut der Standortalteste.

17). Uber alie Angelegenheiten des Zeitfreiwilligendienst und des Binsatzes ist der 3eitfreiwillige nichtulliturischen Dienststelle oder Personen gegeniber zun Schweigen verpflichtet.n

Der Standortalteste

Smidt

Hauptmann. 
de under retssagen, og andre i mindretalsledelsen har påstået, at Kanstein i en skrivelse meddelte, at dette var $i$ orden. Som for nævnt er dette dog ikke korrekt, og Justitsministeriet har oplyst, at der aldrig er ført forhandlinger om udvidelse af "Zeitfreiwilligendienst « til at omfatte danske statsborgere.

Oprettelse af korpset for danske statsborgere behandledes meget hemmelighedsfuldt både fra officiel tysk og hjemmetysk side og blev overhovedet ikke omtalt i Nordschleswigsche Zeitung. Da politiet i Haderslev søgte at indhente oplysninger om korpsets opgaver, beskyldte den tyske værnemagt politiet for militær spionage. Hvervekampagnen indledtes allerede i januar måned 1943, idet samtlige mandlige medlemmer af mindretallet mellem 17 og 60 år fik tilsendt et opråb. Da dette ikke gav det ønskede resultat, blev der efter ordre fra Organisationsamt rettet personlig henvendelse til dem, der ikke havde tilmeldt sig. Henvendelse skete ikke blot til partimedlemmer, men også til ikke-medlemmer. I sidste halvdel af 1944 kom en partibefaling, hvorefter partimedlemmer, der ikke havde meldt sig, nu skulle melde sig. I modsat fald ville eksklusion af partiet blive overvejet.

Ved korpsets opløsning i 1945 var der 1300-1400 medlemmer.

Uddannelsen foregik normalt søndag formiddag og som regel en aften midt $\mathrm{i}$ ugen og bestod i eksercits, riffelskydning (i almindelighed med danske militærgeværer), håndgranatkastning, brug af »Panzerfaust« og gadekampe. Øvelserne foregik i byerne på eksercerpladsen eller i kasernegården og på landet $\mathrm{i}$ almindelighed på de tyske skolers idrætspladser. Deltagerne var udstyret med militære uniformer, medens der kun udleveredes våben under øvelserne. De sidste øvelser afholdtes i marts 1945.

Der aflagdes ikke nogen egentlig ed, men en edslignende erklæring: "Ich verpflichtige mich dem Führer und obersten Befehlshaber der Wehrmacht Adolf Hitler treu zu sein und bin bereit, für ihn mein Leben einzusetzen«.

I det side 304-05 aftrykte "Merkblatt für den Zeitfreiwilligen « - der formentlig stammer fra foråret 1944, på hvilket tidspunkt Hauptmann Smidt, Aabenraa, var leder af hele korpset - er anført detaillerede retningslinier. Dokumentet blev beslaglagt hos et i Aabenraa politikreds fængslet medlem af korpset. Specielt pkt. 16 er interessant.

I en fortrolig skrivelse af 8. juli 1944 fra Wehrmachtsbefehlshaber Dänemark til forskellige værnemagtsafdelinger anføres følgende: „Einsatz der Volksdeutschen kommt bei einer Invasion grundsätzlich nur gegen äusseren Feind in Frage. Hierunter fallen auch Angriffe dänischer Sabotagetrupps gegen von Volksdeutschen bewachte militärische Objekte.«

Ved proklamering af undtagelsestilstanden 29. august 1943 blev korpset indkaldt $\mathrm{i}$ flere sønderjyske byer og indsat til løsning af forskellige opgaver, såsom patruljering på gader og landeveje, vagttjeneste ved jernbanestationer, 


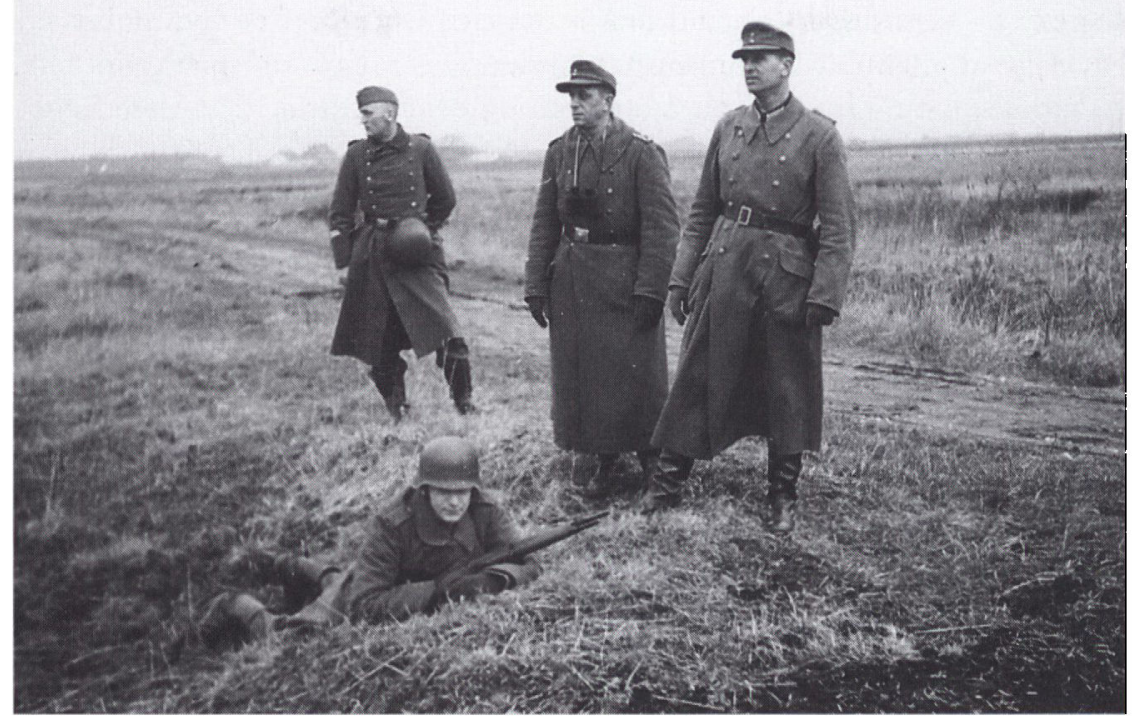

Zeitfreiwillige i aktion. Historiske Samlinger, Aabenraa.

offentlige værker, posthuse, rådhuse og lignende, kontrollering af legitimationskort, udstedelse af køretilladelser og passérsedler, telefonaflytning etc. I Tønder var indkaldt 150, der bevæbnet med riffel og bajonet optrådte meget udæskende og nidkært ved kontrol med mørklægning. I Aabenraa overværede korpsets lokale tillidsmand, lærer Otto Kortsch, »efter ordre « $\mathrm{i}$ uniform og med pistol det første byrådsmøde efter undtagelsestilstanden.

Omkring 20. juli 1944 efter attentatet på Hitler blev korpsets medlemmer i Sønderborg indkaldt til patrulje- og vagttjeneste, lige som et par medlemmer under patruljering med tyske soldater deltog $\mathrm{i}$ anholdelse af en dansk statsborger, der på gaden blev angivet for at have fornærmet den tyske værnemagt.

Den 19. september 1944 ledsagede to Zeitfreiwillige i Haderslev (organist Huth og bogtrykker Georg Kley) nogle tyske soldater, der i forskellige politifolks hjem skulle foretage ransagning efter våben.

\section{Deutscher Selbstschutz Nordschleswig}

Dette korps blev oprettet i begyndelsen af 1944, efter Peter Larsens forklaring på grund af overhåndtagende sabotage, terror og trusler mod tyske virksomheder og personligheder. Der var enighed i det lille politiske råd om oprettelsen.

Lederen af Liefergemeinschaft, ${ }^{9}$ Peter Hansen-Dam, Sønderborg havde på 
organisationens vegne anmodet om beskyttelse af organisationens virksomheder, specielt de mindre, der ikke havde råd til at etablere sabotagevagt. Peter Larsen fik overdraget at organisere korpset med Otto Kortsch som stabschef. Peter Larsen udsendte til korpsets kredsledere et eksemplar af Justitsministeriets cirkulære om fabriksværnets opgaver, og denne instruks har været rettesnoren for korpsets arbejde.

Korpsets medlemmer rekrutteredes hovedsagelig blandt SK-medlemmer, og de anvendte SK-uniformen. Bevæbningen var pistol. Patruljerne havde ikke egentlig politimyndighed. Efter Peter Larsens forklaring havde de instruks om at aflevere eventuelt anholdte mistænkelige personer til det danske politi eller Ortskommandanten.

Den 16. februar 1944 publiceredes i Nordschleswigske Zeitung i stort format, at Folkegruppeføreren havde anordnet oprettelse af korpset, idet opgaven var at træffe de forholdsregler, der er nødvendige for at øge beskyttelsen af det tyske mindretal i Sønderjylland. Korpset talte ialt 400-450 mand. Der var 7 kredsledere. Henimod krigens slutning blev korpset forsynet med maskingeværer $\mathrm{og}$ håndgranater.

I adskillige tilfælde er korpset gået ud over et sabotageværns funktioner, bl.a. i Kruså, hvor man anbragte gidsler i den tyske skole, i Graasten, hvor man patruljerede sammen med tysk militær, i Augustenborg, hvor man anholdt en mand, der havde en maskinpistol på sin cykel og afleverede ham til Gestapo. I Aabenraa og Graasten afholdt man øvelser bl.a. med standsning af passanter og undersøgelse af disses legitimation.

I rundskrivelse af 10 . november 1944 fra stabschef Kortsch til kredsmandskabsførerne udtales, at man skal optage forbindelse med enheder af Gestapo, feltgendarmeriet m.m., idet det ved evt. chikanering af patruljerne vil være muligt at arrestere sådan en fyr og overgive ham til de ovennævnte enheder, så den pågxldende muligt kunne gøres usynlig $i$ et par dage. I en skrivelse fra den lokale fører i Aabenraa omtales øvelser i mørke, færden i mørk skov eller mark, forsvar og angreb på depoter, bevogtning og sprængning af broer, indfangning og tilintetgørelse af sabotørgrupper.

Alt dette måtte naturligvis vække bekymring på dansk side, og den 29. februar 1944 udtalte Udenrigsministeriet $i$ en skrivelse til dr. Best: »Den danske centraladministration har med bekymring taget dannelsen af Selbstschutz inden for det tyske mindretal i Sønderjylland til efterretning og må tage afstand fra, at der inden for en politisk bestemt fraktion skabes en magtfaktor på en måde, der ikke er forudset i lovgivningen «. I sit svar af 9. marts 1944 til det danske Udenrigsministerium anførte dr. Best, at korpset var oprettet, fordi det danske politi havde svigtet, hvorfor ledelsen af mindretallet havde besluttet sig til ufortøvet at lade Selbstschutz træde i virksomhed inden for 
rammerne af S.K. til fælles beskyttelse af virksomheder og personer mod lovstridige angreb.

4 maskinpistoler, 4 maskingeværer og 40 kasser håndgranater blev leveret til Selbstschutz dels fra København, dels fra Volksdeutsche Mittelstelle i slutningen af krigen. Ved dommen blev det fastslået, at korpset havde virket $\mathrm{i}$ tilknytning til besættelsesmagten mod danske statsborgere og iøvrigt havde udøvet virksomhed af politimæssig karakter.

\section{Skansegravning}

I september 1944 bestemte Oberkommando der Wehrmacht, at der skulle etableres en skansegrav (tankspærring) tværs over Sønderjylland fra Haderslev til Rejsby med det formål at hindre en invasionsstyrkes kampvogne $i$ at rykke frem.

Mens dyrlæge Møller opholdt sig på dr. Bests kontor på Dagmarhus, ringede general v. Hanneken, idet der skulle skaffes arbejdskraft til udførelse af gravearbejdet. v. Hanneken havde i tankerne at få rigstysk arbejdskraft samt arbejdere fra O.T.-firmaer ${ }^{10}$ og endelig fra den tyske folkegruppe i Sønderjylland. Dyrlæge Møller har forklaret, at v. Hanneken lagde pres på ham, ligesom han nævnte, at de Zeitfreiwillige kunne indkaldes til udførelse af gravearbejde. v. Hanneken krævede ifølge dyrlæge Møller 5.000 mand.

Dr. Best har oplyst, at v.Hanneken havde bedt ham om at skaffe arbejds-

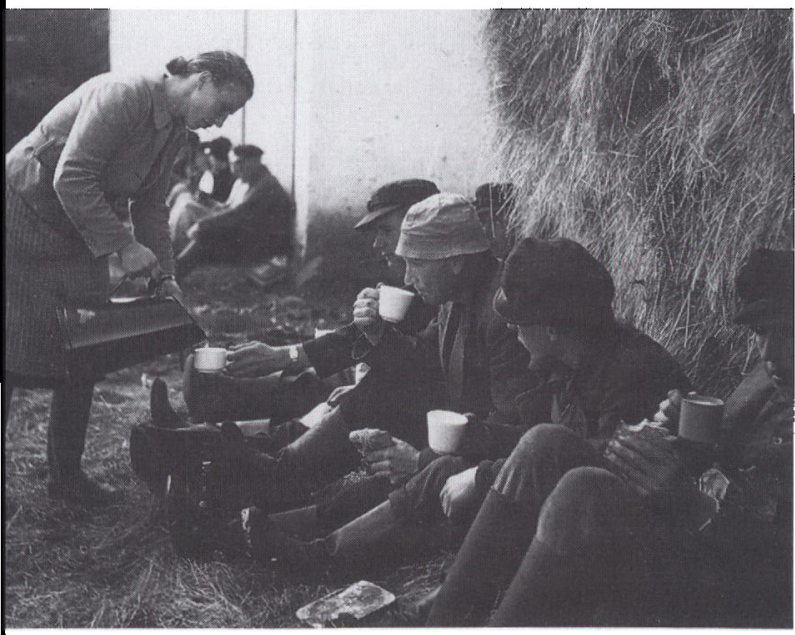

Fra mindretallets skansegravning $i$ 1944. Efter det härde arbejde $i$ den dybe grav kunne koner og unge piger opvarte med kaffe eller malkesuppe. Historiske Samlinger, Aabenraa.

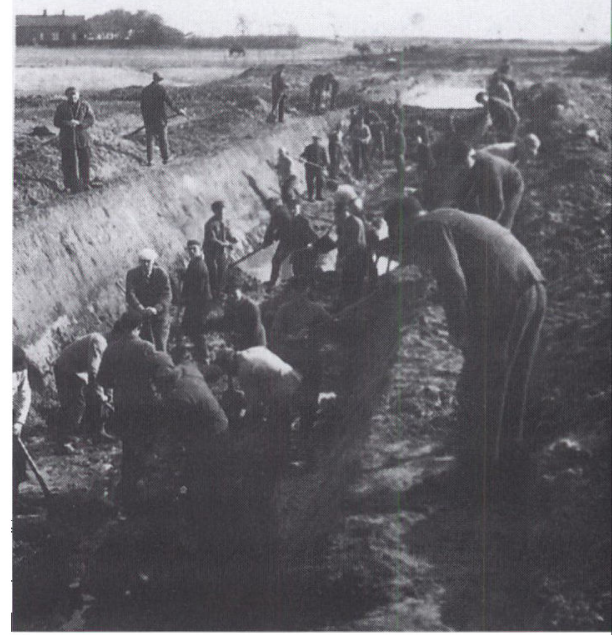


kraft, og de var blevet enige om at opfordre den tyske folkegruppe til frivillig indsats. v.Hanneken fremsatte ikke noget direkte tryk på dr. Best, men denne fik det indtryk, at værnemagten evt. ville gennemtvinge arbejdet ved tvangsarbejde, og han lagde derfor stærkt pres på dyrlæge Møller og gjorde ham bekendt med faren for, at der ville blive foretaget tvangsudskrivning blandt den danske befolkning.

Dyrlæge Møller sagde $\mathrm{ja}$ og forelagde sagen $\mathrm{i}$ rådet og overlod til Peter Larsen at udsende opråb og iøvrigt også ved personlige skrivelser at agitere for udførelsen af arbejdet, der fandt sted fra 10. september til 14. oktober 1944. 2000 personer meldte sig, ligesom der mødte 30-40 hestekøretøjer. I lønninger udbetaltes godt $700.000 \mathrm{kr}$. (daglønnen var $20 \mathrm{kr}$.).

Under hensyn til at folkegruppens partiapparat blev stillet til rådighed ved organisering af arbejdet, der var af ekstraordinær karakter og af direkte krigsmæssig betydning, fandt retten, at der for rådets medlemmer forelå overtrædelse af straffelovstillæggets $\S 16$, stk. $1, \mathrm{nr} .8$.

\section{Grænseflytningsbestræbelser}

Det tyske mindretal kunne ikke affinde sig med den efter afstemningen 10. februar 1920 fastlagte grænse. Man var også utilfreds med, at forhandlingerne om afstemningen og fastlæggelse af grænsen skete ved forhandlingerne mellem Danmark og konferencen i Versailles. Man havde ønsket direkte forhandlinger mellem Tyskland og Danmark.

Mindretallets folketingsmand pastor Schmidt-Wodder gav i sine taler også i Folketinget - udtryk for utilfredshed med Versaillestraktatens løsning. Grænserevisionskravet stod allerede $i$ den tyske vælgerforenings program fra 1921. (Først efter kapitulationen efter 2. verdenskrig i 1945 afgav mindretallet en loyalitetserklæring med anerkendelse af 1920-grænsen). Utilfredsheden med 1920-grænsen blev ikke mindre efter nazificering af mindretallets organisation, da dyrlæge Møller blev Parteiführer.

Man havde set, at Hitler efterhånden havde tilbagetaget alle områder, der var frataget Tyskland ved Versailles-traktaten - bl.a. Sudeterlandet, AlsaceLorraine og Eupen-Malmedy. Man fik fabrikeret postkort, hvor jernlænker alle steder var revet i stykker. Kun ved grænsen til Nordslesvig eksisterede lænkerne endnu.

Efter Hitlers magtovertagelse kom paroler som: »Führer mach uns frei!« og »Heim ins Reich» hyppigere frem på møder og også i tidsskrifter og bøger. Det var derfor hos nogle en stor skuffelse, at grænsen ikke blev flyttet ved besættelsen af Danmark 9. april 1940. 
Fra rigstysk side havde man adskillige gange gjort mindretallet opmærksom på, at grænsen ikke skulle ændres. Dyrlæge Møller var efter et opråb om grænseflytning i 1939 af det tyske Udenrigsministerium truet med at blive afsat som Folkegruppefører. Således blev der kort efter 9. april 1940 sendt en repræsentant for Volksdeutsche Mittelstelle - Obersturmführer Rimann - til Aabenraa for at precisere det rigstyske standpunkt, der vakte stor utilfredshed.

Dyrlæge Møller fortsatte med at lufte grænserevisionsspørgsmålet og udtalte bl.a. på et møde i Kjelstrup 29. juli 1940:" ${ }^{11}$ Man taler meget om grænsen, nogle siger den kommer til at ligge ved Aabenraa, andre påstår ved Hoptrup etc. Det er altsammen noget vrøvl, som grænse kan der kun være tale om Kongeåen. Jeg ikke alene tror det, jeg ved det. Køb De roligt flag og flagstænger.« Tæppehandler Max Clausen, Sønderborg, der rejste i dyrlæge Møllers kølvand, havde rivende afsætning af hagekorsflag.

I Sønderjylland gik der i maj og juni 1940 mange rygter om, at grænsen ville blive flyttet på årsdagen for Versaillestraktatens underskrivelse 28 . juni. Disse rygter forplantede sig også til det tyske gesandtskab og den danske regering. Den 20.juni 1940 afsendte gesandt Renthe-Fink følgende telegram til Udenrigsministeriet i Berlin:

"København den 20. juni 1940 kl. 16.50

Ankomst den 20. juni $1940 \mathrm{kl}$. 17.20 .

Nr. 699 af 20.6.

Til gesandt von Grundherr.

Konsulat Aabenraa melder den 19. d.m.:

I folketyske kredse stærkt udbredt rygte om, at den gamle grænse mellem Tyskland og Danmark i løbet af de nærmeste dage skulle blive genoprettet, og at dyrlæge Møller er kaldt til Berlin til forhandlinger vedr. grænsespørgsmålet. Anser det for rigtigt, at Volksdeutsche Mittelstelle informeres.

sign. Renthe-Fink «

Og den 28. juni 1940 et supplerende telegram:

»Telegram-åbent. Hemmeligt nr. 135.

København den 26. juni 1940 kl. 0.50

Ankomst den 26. juni $1940 \mathrm{kl} .2 .15$

Nr. 717 af 25.6 .

I tilslutning til telegrafisk rapport nr. 699 af 20.6. Statsminister Stauning og udenrigsminister Munch, som i går havde bedt mig komme til dem til en samtale, berørte ved denne lejlighed også rygter, der går om 
forestående begivenheder i Nordslesvig. Jeg svarede, at jeg ikke kendte noget til det.

Her regnes almindeligt med den mulighed, at Føreren den 28. juni vil erklære Versailles-diktatet for annulleret, og at der derved vil opstå en ny situation for Nordslesvig. I indsigtsfulde kredse gør man sig fuldstændig klart, at en grænsedragning, der hviler på Versailles-diktatet, vanskeligt tåles af Tyskland, dog skorter det på beslutsomhed og mod til fra dansk side at tage initiativet og tilstræbe en forståelse med Tyskland om det nordslesvigske spørgsmål. Man hengiver sig samtidig til håbet om, at den nuværende grænse er garanteret ved tilsikringen af territorial integritet $i$ det tyske memorandum af 9 . april.

Renthe-Fink«

I tiden efter 9. april 1940 lod mindretalsledelsen dr. Peter Kragh udfærdige en befolkningspolitisk undersøgelse, der skulle anvendes som dokumentation for, at det tyske element i Sønderjylland var langt større end de virkelige forhold udviste. Redaktør Ernst Schrøder indrømmede dog senere ved en afhøring i Aabenraa, at redegørelsen var meget tendentiøst affattet.

Ved en afhøring i 1947 i straffelejren Esterwegen fortalte Slesvigs-Holstens tidligere Gauleiter Hinrich Lohse mig, at han to gange drøftede grænserevisionsspørgsmålet med Hitler. Første gang var i 1939 ved en stabelafløbning i Kiel. Konklusionen af samtalen var, at grænsen ikke skulle flyttes, da 1) Sønderjylland ikke var rigt på mineraler, men kun rummede landbrugsjord, 2) ved grænseflytning ville man få besvær med en stor dansk folkedel, og 3) Hitler havde jo Flensborg by og fjord, hvor den tyske flåde kunne søge tilflugt, hvis det blev "for varmt« i Kiel. Ved den anden drøftelse - det var omtrent samtidig med det betydningsfulde folketingsvalg i april 1943 - var argumentationen og resultatet det samme. Hitler ville ikke på grund af grænsespørgsmålet lægge sig ud med Danmark og hele Norden, idet han mente, at disse lande efter krigen selv ville slutte sig til Tyskland. Den storgermanske tanke har vel været afgørende for Føreren.

Mindretallets utilfredshed med det rigstyske standpunkt blev stadig holdt ved lige i tale og skrift. Man skildrede, at man blev udspioneret af det danske politi, blev truet med hævn, når de tyske tropper blev trukket tilbage og frygtede voldshandlinger. Sådan lød det også i indberetninger til gesandtskabet fra den tyske konsul i Aabenraa, der tilføjede, at han »nærede ængstelse af lignende art«.

Ved det ovenfor næunte møde den 12. april 1940 på Stadttheater i Aabenraa, hvor Obersturmführer Rimann som repræsentant for Volksdeutsche Mittelstelle forklarede, at der ikke kunne blive tale om grænseflytning, rejstes spørgsmå- 


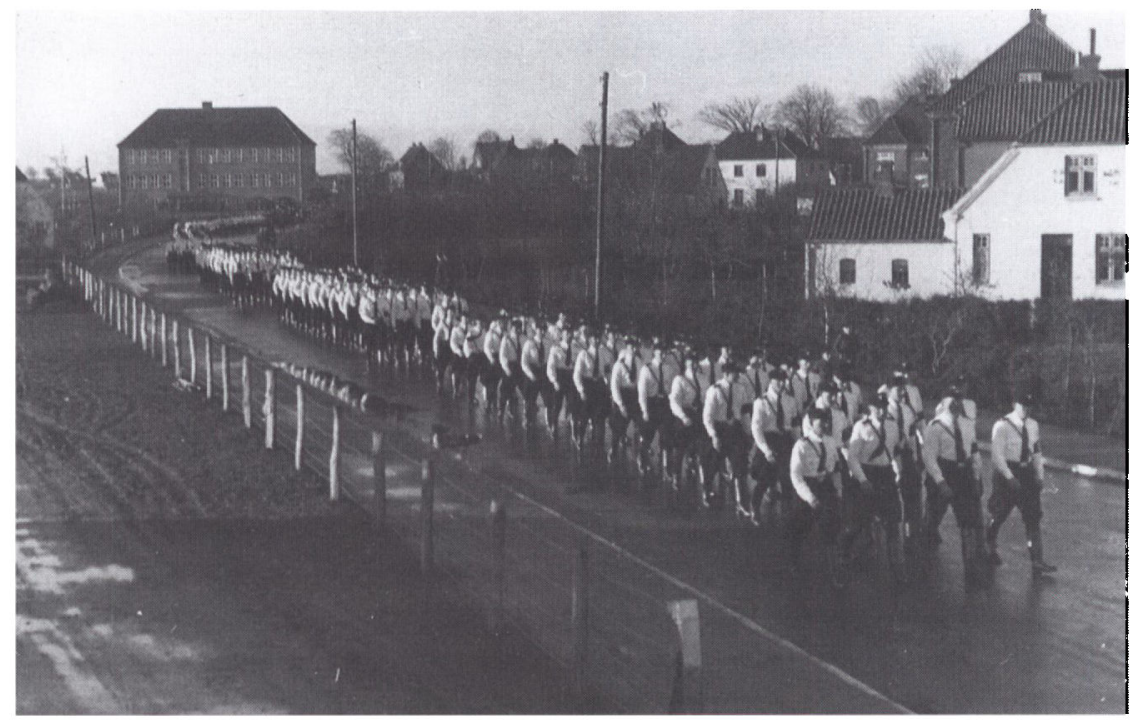

Uniformerede medlemmer af Schleswigsche Kameradschaft og Deutsche Jungenschaft Nordschleswig marcherer her den 29. november 1942 gennem Graasten for at markere indvielsen af den nye tyske skole, som ses i baggrunden. Den imponerende bygning var finansieret ved direkte trak pả besattelsesmagtens konto i Nationalbanken. Efter krigen hlev bygningen beslaglagt, og politiet tog den i brug som politigård. Historiske Samlinger, Aabenraa. NSDAPN's billedarkiv.

let, om der slet ikke var noget at gøre. Hertil svarede Rimann, at man i Sudeterlandet havde indsendt indberetninger angående overgreb, "Gehässigkeiten «, mod Sudetertyskerne - boykot, trusler, voldshandlinger m.v. Man fik så besked på, at det kunne man også gøre her.

Og så gik mindretallet $i$ gang med at sende indberetninger til partiet, der videresendte dem til Volksdeutsche Mittelstelle med kopi til det tyske konsulat i Aabenraa. Herfra gik de videre til gesandtskabet, der igen lod dem gå til Udenrigsministeriet i Berlin. Her fandt man under efterforskningerne den skrivelse af 21 . oktober 1940 fra partiledelsen i Graasten, som er gengivet side 314-15. Skrivelsen er uden underskrift, men må stamme fra Jens Møller. Den var ledsaget af 147 stk indberetninger, og det fremgår, at både skrivelsen og bilagene var afleveret i det tyske Udenrigsministerium af Dr. Sichelschmidt fra Volksdeutsche Mittelstelle den 26. eller 27. august 1942, senest inden kl. 12 middag den 27.'2

Skrivelsen taler klart om behovet for nu endelig at fore hele Slesvig sammen under tysk førerskab. Sammen med de i øvrigt foreliggende oplysninger gav skrivelsen grundlag for, at Justitsministeriet rejste tiltale mod Jens Møller og Peter Larsen for overtrædelse af straffelovens $\S 98$, jfr. $\S 8$ i straffelovstillægget 


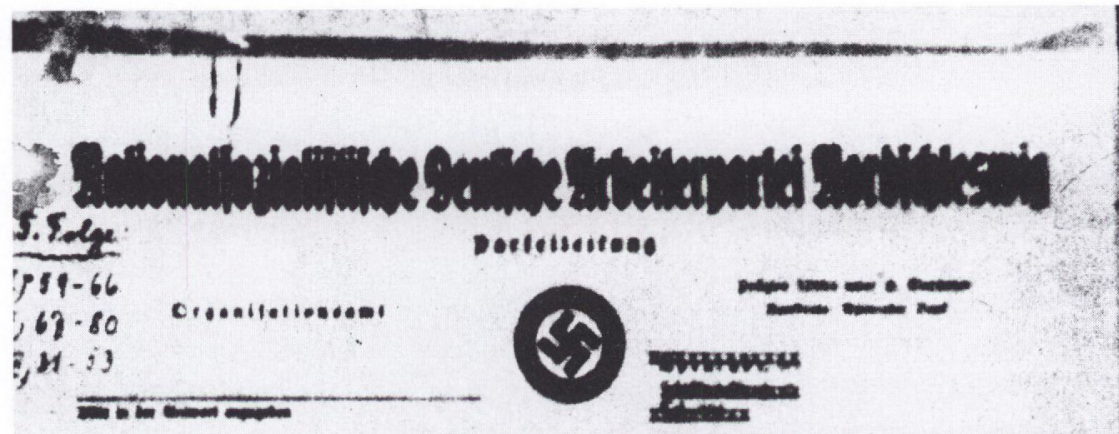

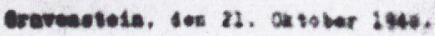

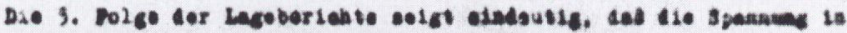

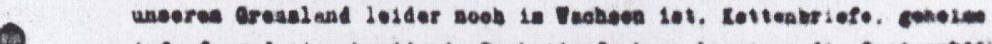

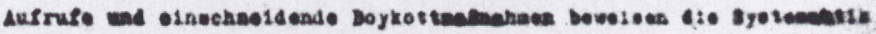

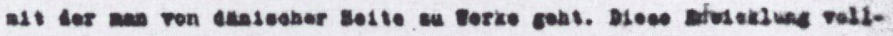

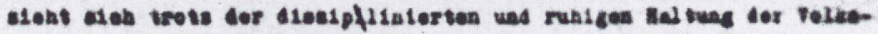

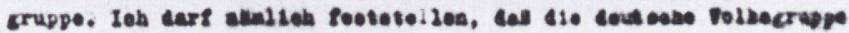

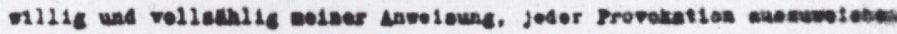

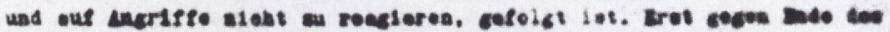

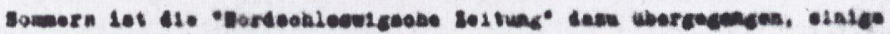

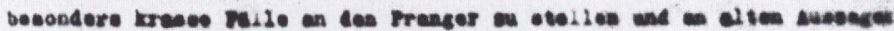

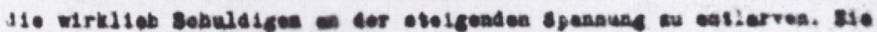

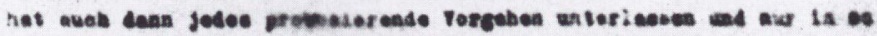



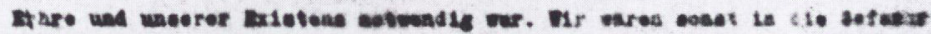

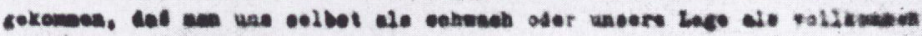

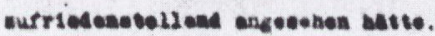

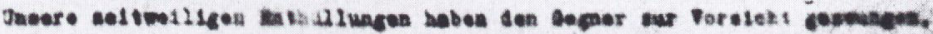

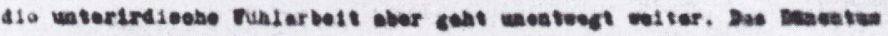

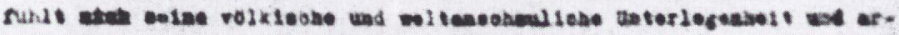

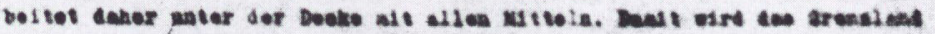

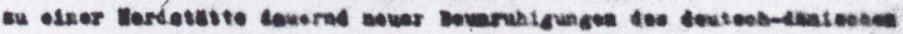

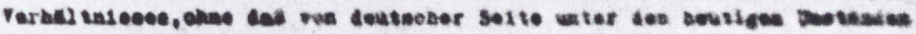
s1. Mage cetidert wenles roumb.

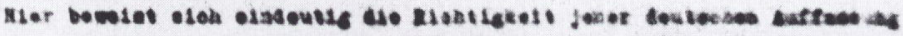

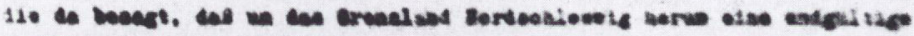

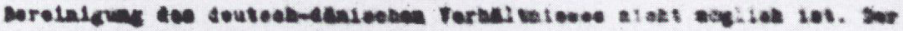

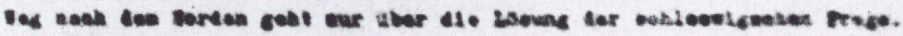

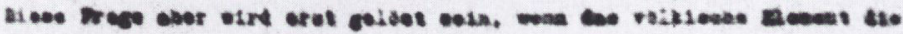

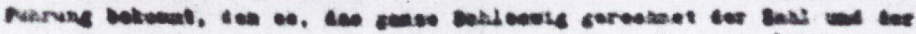
ก $5: \cdots+$;

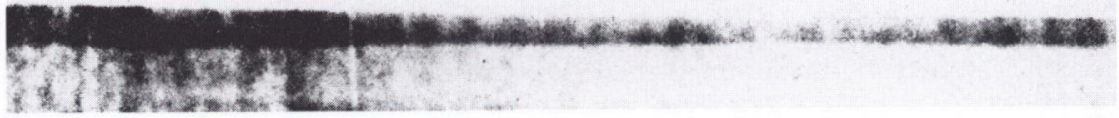




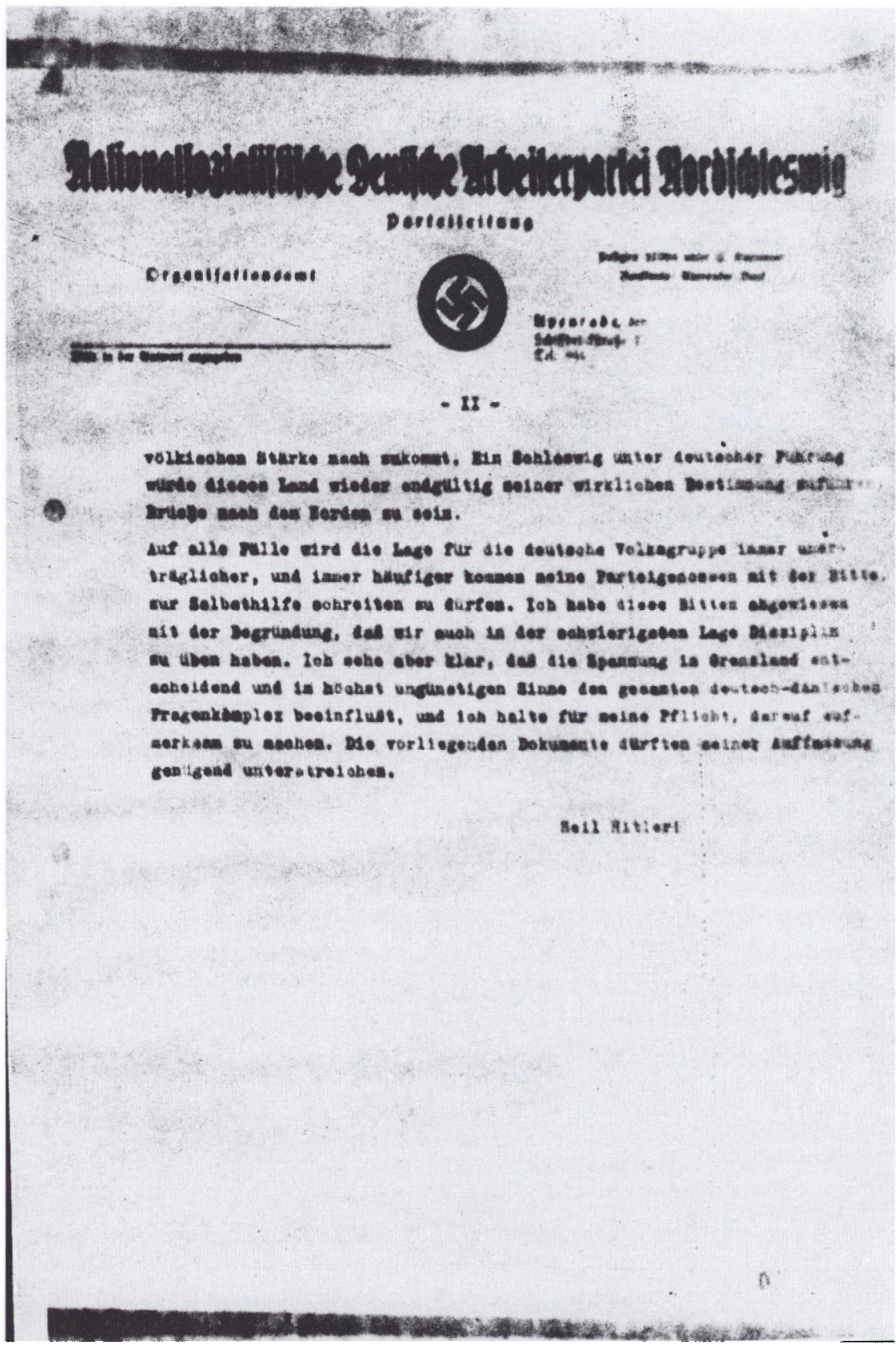

Brevet af 21. oktober 1940 vedr. mindretallets granseflymingsbestrabelser gengives her efter en desvarre noget dårlig fotokopi ikke utypisk for det kildemateriale, sam historikerne md benytte. 

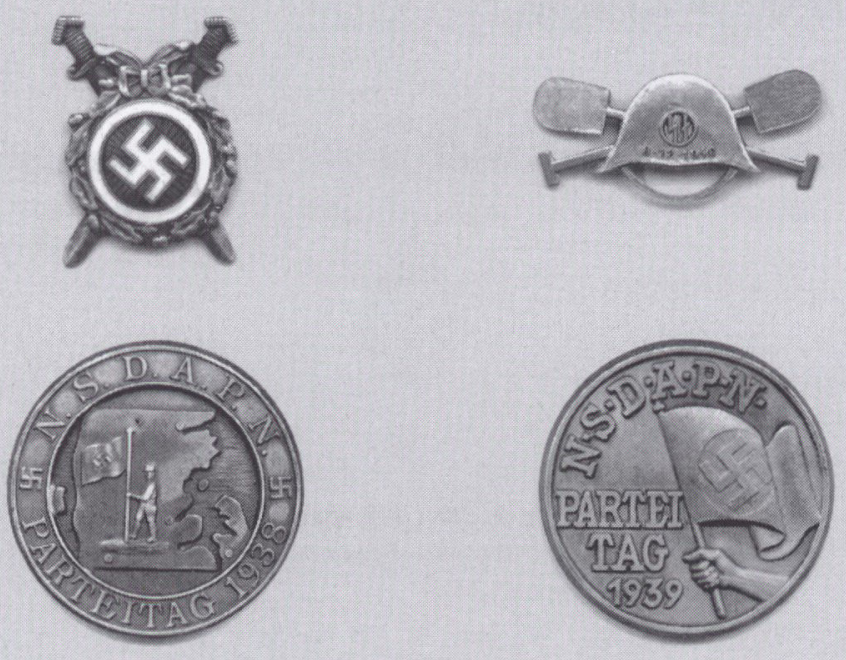

På fotos fra tiden 1933-45 kan man se nazister og medlemmer af mindretallet $i$ Nordslesvig smykket med emblemer af flere slags. Her gengives et beskedent udvalg. Øverst til venstre et waresemblem for frontkamperes indstiftet af DNSAP og tildelt frontkampere, som samtidig var partimedlemmer. Hagekorset er hvidt pad rod bund $i$ modsatning til de tilsvarende tyske emblemer, som viser et sort hagekors på hvid grund $i$ rod ring.

Overst til hojre whaderstegn for arrestanter" fra SA- demonstrationstoget i Haderslev 8.12.1940, det säkaldte "spadeslag."

Nederst emblemer fra NSDAPN's partidage 1938 og 1939. På emblemet fra 1938 ses Nordslesvig og en Nazi-fanebarer. Emblemerne er gengivet i naturlig storrelse. Jorgen Bendorffs samling, Tonder. Foto Helge Krempin.

af 6. juli 1946 »i anledning af, at han i sin egenskab af leder af partiet NSDAPN over for tyske myndigheder, således som det fremgår af en skrivelse af 21. oktober 1940 fra det næunte partis partiledelse, har fremstillet forholdene for det tyske mindretal som stadig mer uudholdelige og fremhævet betydningen af et Nordslesvig under tysk herredømme, hvorved han, når denne optræden ses på baggrund af de daværende forhold, har udfoldet bestræbelser, der sigtede til ved magtanvendelse eller trusel om sådan at bringe en del af den danske stat under fremmed herredømme «.

Ved dommen skete frifindelse med følgende præmisser: "Under sagen er der således ganske vist fremdraget talrige beviser for, at mindretallet og dets ledere, herunder tiltalte Møller, levede $\mathrm{i}$ håbet og forventningen om en grænserevision, men det fremgår tillige af det oplyste, at man (også tiltalte) efterhånden, om end med resignation og skuffelse, rettede sig efter de rigstyske direktiver om 
- $\mathrm{i}$ hvert fald foreløbig - at skrinlægge revisionskravet og bøje sig ind under det større perspektiv, der indeholdtes i den «storgermanske tanke«.

Set på denne baggrund, og når derhos henses til, at ... skrivelsen af 21.10.1940 efter sin ordlyd ikke indeholder nogen direkte opfordring til grænseflytning, endsige til grænseflytning ved magtanvendelse eller trusel om sådan (selv om en grænseflytning under de da herskende forhold næppe kunne tænkes etableret på anden måde end ved magtbud fra det nazistiske Tysklands side), har retten ikke fundet, at tiltalte Møller har gjort sig skyldig i overtræelelse af straffelovens $\S 98$, og han vil derfor forsåvidt være at frifinde.

Hertil kan tilføjes, at den omstændighed, at skrivelsen af 21.10 .1940 først afleveres $i$ det tyske Udenrigsministerium ca. 2 år efter modtagelsen $i$ »Vomi« synes at tyde på, at man ikke fra "Vomi«s side har tillagt den presserende betydning ${ }^{13}{ }^{13}$

Hermed vil jeg slutte min beretning fra retsopgørets spændende år. Mindretallets grænseflytningsbestræbelser har i dag kun historisk interesse. Efter loyalitetserklæringen i 1945 er verden nu en helt anden.

\section{NOTER OG HENVISNINGER}

Artiklen bygger på personlige erindringer og aktstykker i forfatterens privateje. Desuden er benyttet aktstykker $\mathrm{l}$ landsarkivet (Aabenraa politis arkiv, især sager vedr. dommen over Jens Møller og Peter Larsen).

1. Peter-gruppen var en tysk terrorgruppe. Den bestod af lederen Peter Schwerdt (daknavn Schäfer) med flere tyske og danske medlemmer. Den sorterede under Bovensiepen. 2 tyskere og 1 dansker deltog $\mathrm{i}$ sprængningen, der var gengaldelse for politiets passive holdning ved sabotageaktionen 6. februar 1944 j Aabenraa mod Callesens Motorfabrik.

2. Zeitfreiwillige: mindretalsmedlemmernes frivillige deltidstjeneste i Nordslesvig, i modsæatning til de egentlige frivilliges indsats ved fronterne.

3. Kleiner politischer Rat: Det lille politiske råd afløste efter besattelsen det hidtil eksisterende politiske råd, der med sine $40-50$ medlemmer var for stort og uhandeligt. Det lille politiske råd drøftede alle mindretallets væsentlige politiske spørgsmål og fastlagde retningslinjerne for politikken. Rådet bestod var ca. 15 personer, nemlig partifører Jens Møller (dyrlæge), lederen af Organisationsamt Peter Larsen (Oberleutnant), leder af Amt für Presse und Propaganda Peter Rudolph Stehr (jurist), leder af Schatzamt Peter Petersen (bankmand), stabsleder i Deutscher Selbstschutz Otto Ferdinand Kortsch (lærer), redaktør af Nordschleswigsche Zeitung Harboe Friedrich Wilhelm Kardel, Landesschulungsleiter Asmus Wilhelm Jürgensen (lærer, "Asmus von der Heide (), leder af Kulturamt Peter Andersen Callesen (lærer), Desuden af kredslederne fra Haderslev: Lauritz Clausen (advokat), Aabenraa: Jep Marcussen Schmidt (gårdejer), Tinglev: Heinrich Ehnstedt (gårdejer), Tønder: Jes Peter Petersen (lærer), Sønderborg: Wilhelm Deichgräber (gårdejer). 1942 aflest af Christian Johannsen Roth (lokalredaktor).

4. Selbstschutz der Volksgruppe: sabotageværn, især rekrutteret fra Schleswigsche Kameradschaft.

5. Volksdeutsche Mittelstelle (VOMI) var et partikontor, især bemandet med SS-officerer, til koordinering af mindretalsarbejdet. 
6. S.K. $=$ Schleswigsche Kameradschaft: mindretallets halvmilitære organisation, bestående af især yngre mænd, der optrådte $\mathrm{i}$ uniform: lange støvler, ridebukser, hvid skjorte og skrårem og uniformshue.

7. D.J.N. $=$ Deutsche Jungenschaft Nordschleswig.

8. FLAK = Flugabwehrkanonen: antiluftskyts.

9. Liefergemeinschaft: en hjemmetysk organisation oprettet kort efter 9. april 1940 med det formål at skaffe hjemmetyske erhvervsdrivende fordelagtige leverancer til værnemagten.

10. O.T-firmaer: Organisation Todt forestod værnemagtens byggearbejder, idet enkelte danske firmaer påtog sig rollen som underentreprenører.

11. Aabenraa rets trykte dom af 10.9 .1948 vedr. Jens Møller p. 51 medio.

12. sst. s. $45-46$.

13. sst. 